\title{
堤防高を考慮した害効的な津波被害想定手法
}

\author{
An Effective Tsunami Damage Estimation Method Considering Dike Height
}

\section{加藤史訓 $^{1} \cdot$ 福濱方哉 ${ }^{2} \cdot$ 藤井裕之 ${ }^{3} \cdot$ 高木利光 ${ }^{4} \cdot$ 児玉敏雄 $^{5}$}

Fuminori KATO, Masaya FUKUHAMA, Hiroyuki FUJII, Toshimitsu TAKAGI and Toshio KODAMA

\begin{abstract}
In Japan, the central and prefectural governments have conducted tsunami damage estimation assuming non-failure of coastal dikes during earthquake and tsunamis. The maximum flood depth, from which damages to houses and humans were estimated, would vary with dike subsidence caused by earthquake motion, tsunami-induced dike failure, and topography in the hinterland. Many cases of tsunami simulation considering dike subsidence etc. are necessary for practical damage estimation, but cost much time and expense. Therefore, we developed an effective tsunami damage estimation method that does not need complicated tsunami simulations.
\end{abstract}

\section{1.はじめに}

中央防災会議や地方自治体では想定される地震につい て津波の浸水予測計算を実施し, 家屋や人的被害の推定 を行っている. しかし, それら想定では地震に伴う海岸 堤防の沈下状況を詳細にモデル化していないといった問 題がある．津波被害の現実的な推定には，津波来襲直前 の堤防高を適切に条件設定する必要がある。一方, 地震 に伴う堤防沈下については, FEM 解析などによって定 量的に堤防の沈下量を評価する方法が実用化されつつあ る.これら堤防の沈下量を適切に評価し, 被害想定を行 うことが今後の津波対策を実施していく上で重要である と考えられるが, 平面 2 次元津波遡上計算の新たな実施 は費用・時間を要し，堤防沈下などを想定した多数のケ 一スの計算は大きな負担である。 そこで，想定されてい る津波高, 防護施設の諸元, 背後地の地形から, 簡易に 最大浸水深および家屋・人的被害を想定する手法を検討 した.

\section{2. 研究內容}

以下のような被害想定手法を提案し，その妥当性を検 証した。

1) 中央防災会議などの津波シミュレーション結果から 海岸での最高水位を把握

2）想定津波の周期が不明の場合，地震による地盤変動 の鉛值変位分布から波長を推定し，周期に換算

3 ）津波の諸元と堤防高から総越流量を算定

\begin{tabular}{|c|c|c|}
\hline I正会員 & 工修 & $\begin{array}{l}\text { 国土交通省国土技術政策総合研究所 } \\
\text { 河川研究部海岸研究至 主任研究官 }\end{array}$ \\
\hline 2 正 & 工修 & $\begin{array}{l}\text { 国土交通省国土技術政策総合研究所 } \\
\text { 河川研究部海岸研究室長 }\end{array}$ \\
\hline & 修(工) & (株)アイ・エヌ・エー海岸部 \\
\hline & 博 (工) & (株)アイ・エヌ・エー海岸部 \\
\hline & 博(工) & (株)アイ・エヌ・エー海岸部 \\
\hline
\end{tabular}

4 ）総越流量から遡上先端距離を算定（レベル湛水法）

5 ）津波や地形の諸元から堤防内側の最高水位を算定

6 ）堤防内側の最高水位と遡上先端を結ぶ線を最高水位 分布とする

7 ) '最大浸水深分布（最高水位分布と地盤高との差）か ら家屋・人的被害を算定

2）の妥当性については, 宮城県沖地震を対象に検証 した. 3）〜 6) については，1 次元津波遡上計算によ り, 堤前の最高水位と総越流量との関係整理, レベル湛 水法（農林水産省・国土交通省，2004）で得られる津波 遡上距離との比較, 堤防内外の最高水位の関係整理, 最 高水位の岸沖方向の変化把握を行い検討した. 7) につ いては，高知海岸仁ノ工区を対象としたケーススタディ により, 本手法と平面 2 次元津波遡上計算の結果を比較 した.

\section{3. 津波周期の設定}

津波の周期が不明の場合，以下のような手順で周期を 設定することとした.

線形長波理論では, 周期 $T$ と波長 $L$ の関係は以下の 式で表される。

$$
T=L / \sqrt{g h}
$$

ここで, $h$ : 最大鉛直変位地点の水深である.ここでは, 津波の発生原因となる地盤の鉛直変化量から津波の波長 を決定することとし，波長は以下のように計測する.

(1)岸沖方向の鉛直変位分布が正弦波の形状をしている場 合には，岸沖方向の鉛直変位距離を 1 波長の長さとし て計測する（図-1および 2 ）.

(2)岸沖方向の鉛直変位分布のうち隆起部分が支配的な変 位である場合には, 隆起部分の距離を $1 / 2$ 波長の長さ として計測する（図-1 および3）。

(3)岸沖方向の鉛直変位分布のうち隆起部分が支配的な变 位であり，最大の隆起地点の水面勾配が鉛直に近い場 

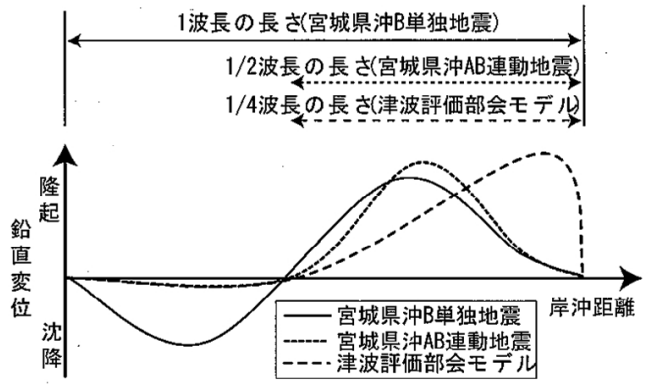

図-1 波長の設定方法

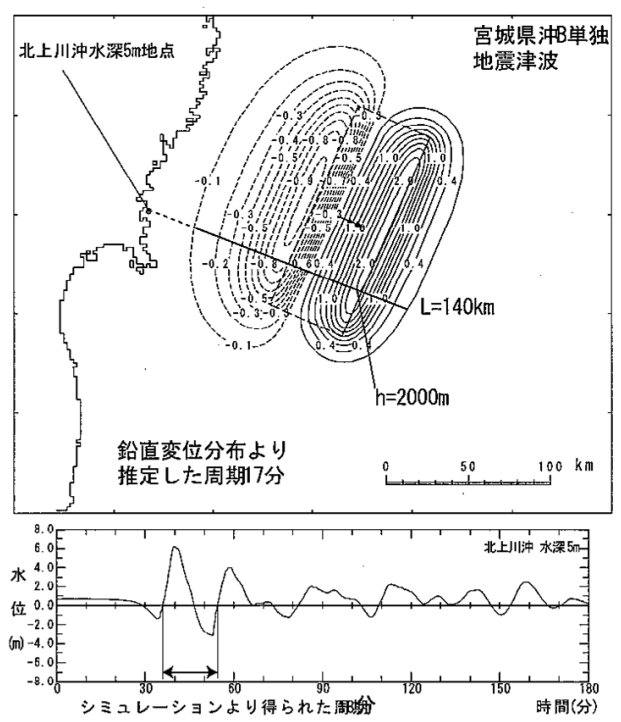

図-2 初期の水位 - 地殸変動量（宮城県沖 B 単独地震）

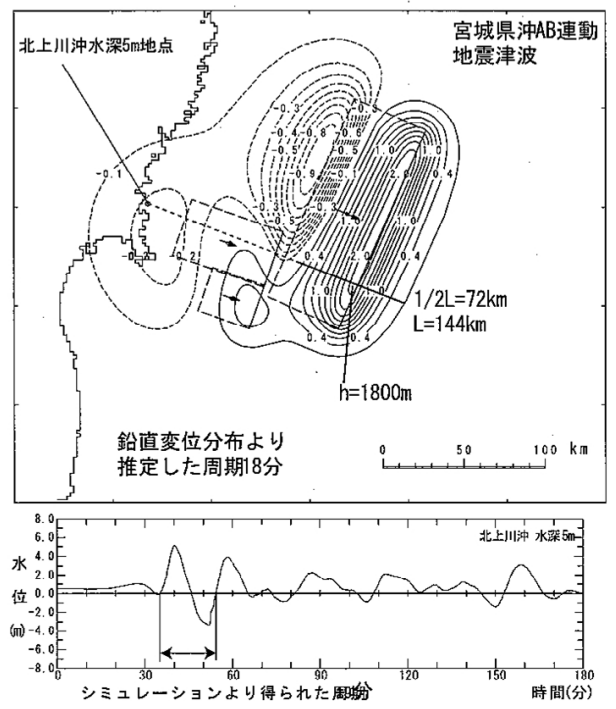

図-3 初期の水位・地殼変動量（宮城県沖 $A B$ 連動地震）

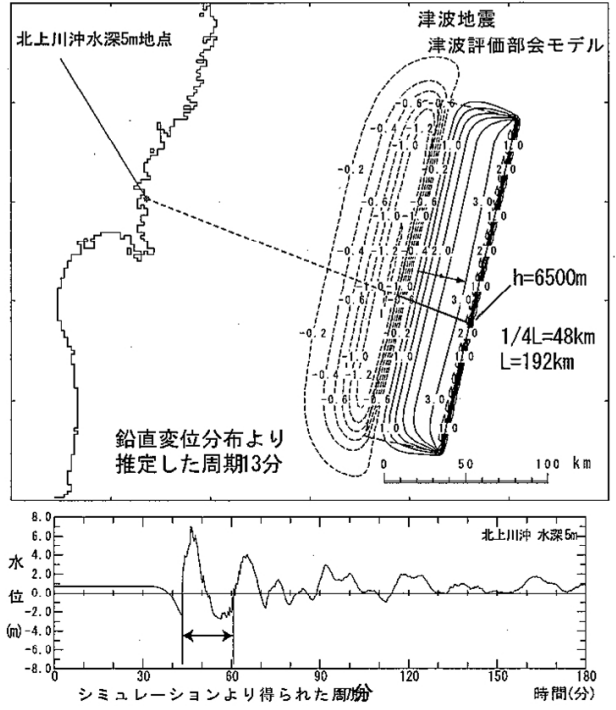

図-4 初期の水位・地殼変動量（津波評価部会モデル）

合には隆起部分の距離を $1 / 4$ 波長の長さとして計測す る(図-1 および4).

図-2〜4のように，本手法で設定した周期は，津波 伝播計算で得られる周期と概ね一致している.

\section{1 次元津波遡上計算によるパラメータスタディ}

図-5に示す地形に対して 1 次元津波遡上計算を実施 して, 堤内地の最大浸水深分布と津波, 堤防, 背後地の 諸元との関係を整理し，簡易的に最大浸水深分布を作成 する方法を提案した.

\section{（1） 1 次元津波遡上計算}

津波遡上計算は，非線形長波方程式を用いて，表-1

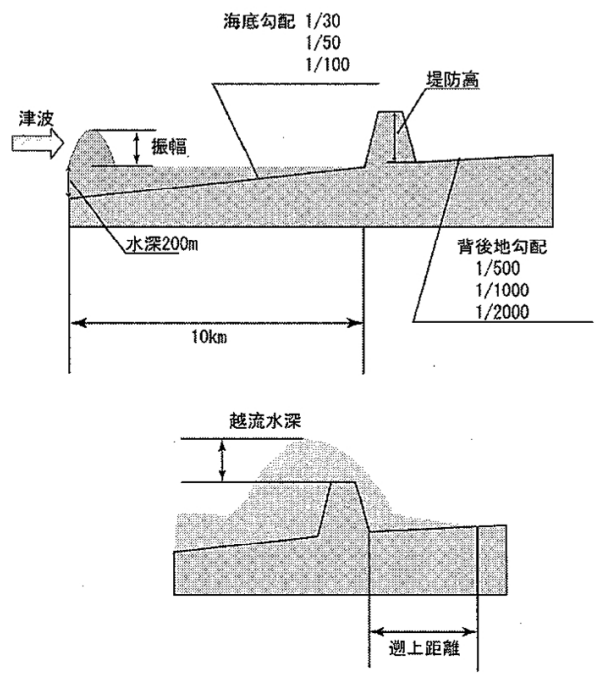

図-51 次元津波遡上計算モデル地形 
表-1 1 次元津波遡上計算ケース

\begin{tabular}{c|c}
\hline 諸 元 & 条 件 \\
\hline 入射波振幅 $(\mathrm{m})$ & $0.5,1.0,1.5,2.0,2.5,3.0$ \\
\hline 入射波周期 $(\mathrm{min})$ & $5,10,20,30$ \\
\hline 堤防高 $(\mathrm{m})$ & $0.0,2.5,5.0,7.5$ \\
\hline 海底勾配 & $1 / 30,1 / 50,1 / 100$ \\
\hline 背後地勾配 & $1 / 500,1 / 1000,1 / 2000$ \\
\hline
\end{tabular}

のように津波の波高および周期 ( $\sin$ 波)，堤防の天端 高, 背後地の地形条件を変えて 864 ケースについて実施 した.

\section{（2）堤前水域の最高水位と総越流量の関係}

周期 $T(S)$ の津波による堤防での越流量が，最大越流 量 $q_{\max }\left(\mathrm{m}^{3} / \mathrm{s}\right)$ を頂点として $a T(S)$ だけ継続する二等 辺三角形の時間的分布で表されるとすると, 総越流量 $Q\left(\mathrm{~m}^{3}\right)$ は式 $(2)$ で表される。ここで， $a$ は越流時間 に関するパラメータである。

$$
Q=\frac{a T}{2} q_{\max }
$$

$q_{\max }$ は本間の越流公式を適用すると式 (3)で表される.

$$
q_{\max }=B C \sqrt{2 g} h_{\max }{ }^{3 / 2} \text {. }
$$

ここで, $B$ : 越流幅 $(\mathrm{m}), C$ : 越流定数 $(0.35), h_{\text {max }}$ : 最大越流水深 $(\mathrm{m})$ である. $H_{\max }$ : 堤前最高水位 $(\mathrm{m})$, $Z_{0}$ : 堤防高 $(\mathrm{m})$ とすると, $h_{\max }$ は式 $(4)$ で表される.

$$
h_{\max }=H_{\max }-Z_{0}
$$

式（2），(3)，(4)より，Qは式（5）で表される.

$$
Q=\frac{a T}{2} B \cdot C \cdot \sqrt{2 g}\left(H_{\max }-Z_{0}\right)^{3 / 2}
$$

一次元津波遡上計算の結果を図-6のようにプロット したところ， $a$ を周期別に設定して式（5）を適用する こと（図中の実線）により総越流量を十分な精度で推算 できることがわかった。

\section{(3) 津波遡上距離の検討}

海底勾配 1/50のケースについて, 式（5）で得られ る総越流量からレベル湛水法で得られる津波遡上距離を 一次元津波遡上計算の結果と比較した（図-7〜9). そ の結果, 堤防がある場合（堤防高 $0.0 \mathrm{~m}$ 以外）では両 者の相違は $10 \%$ 程度に収まった。このことから，レべ 儿湛水法で津波遡上距離を概ね推定できると判断した.

\section{（4）津波遡上距離と背後地最高水位分布の関係}

海底勾配 1/50のケースについて，背後地に扔ける最 高水位の縦断分布を求めた. その結果, 背後地の最高水 位の分布は，堤防の堤内側最高水位と遡上先端位置とを 結んだパターン(1)と，遡上先端よりも海側で水位が十分 低下し，そこから遡上先端位置まで平らになるパターン (2)に大別された（図-10)。また，最高水位の縦断形は， 周期の短い津波の場合には内陸に向かって下がるが, 周

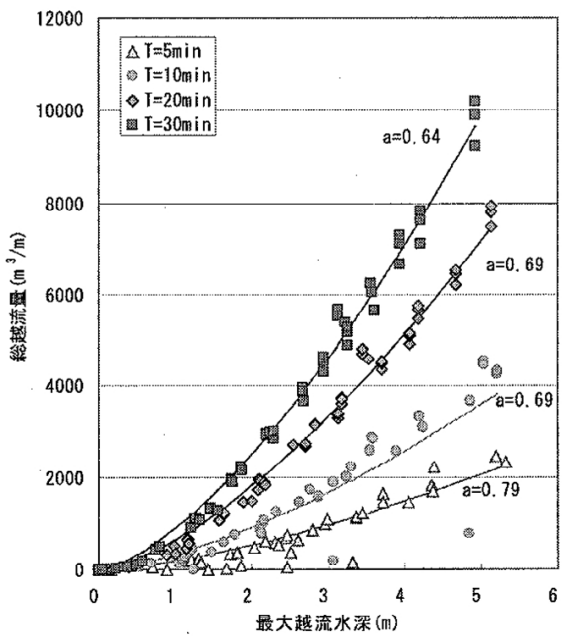

図-6 最大越流水深と総越流量の関係

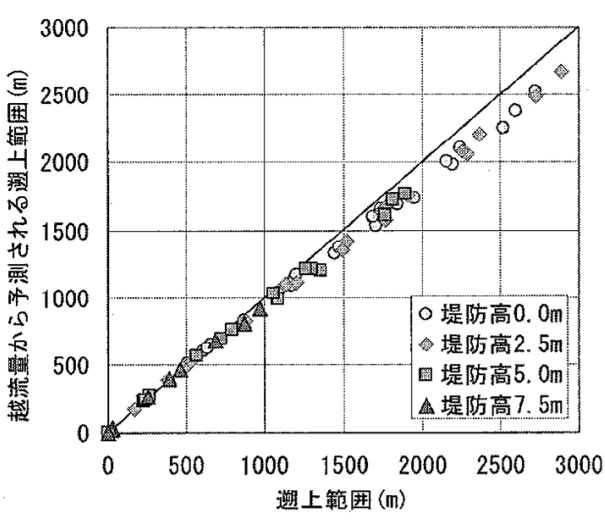

図-7 津波遡上範围（背後地勾配 $1 / 500 ）$

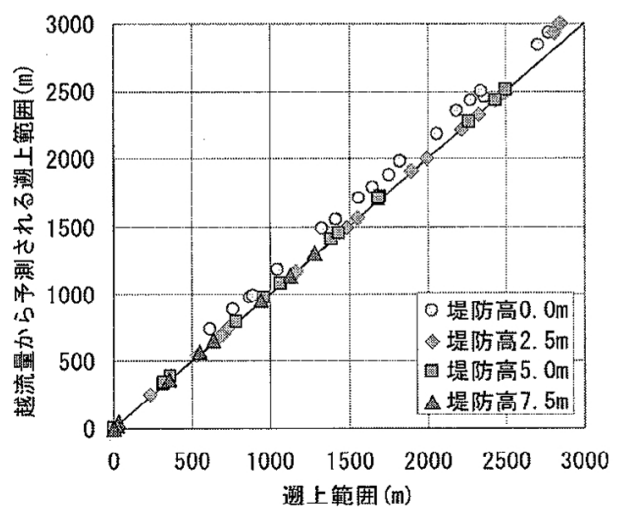

図-8 津波遡上範团（背後地勾配 $1 / 1000 ）$

期の長い津波の場合には水平に近づいた。ささらに，堤防 が高くなると，または背後地勾配が緩くなると，最高水 位の縦断形が地形の勾配に漸近していく傾向が認められ た。

パターン(1)と(2)で得られる最大浸水深から，加藤ら 


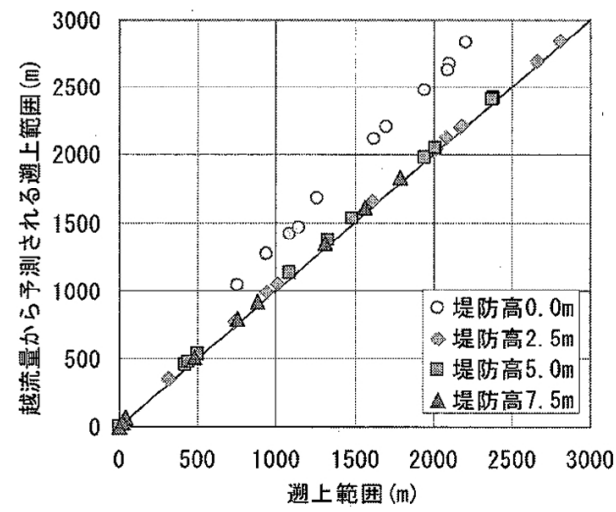

図-9 津波遡上範囲（背後地勾配 $1 / 2000 ）$

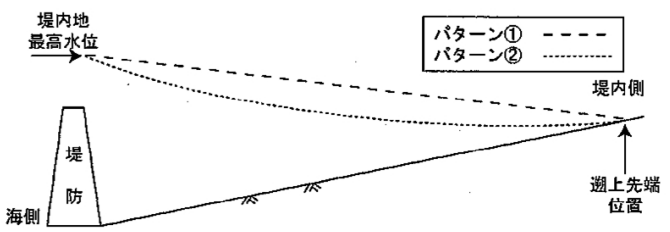

図-10 最高水位の縰断分布パターン

（2006）と同様に, 中央防苂会議「東南海・南海地震等 に関する專門調查会」の被害関数を用いて建物・人的被 害を推定したところ，その差はほとんどないことが確認 された. そこで, 背後地の最高水位分布としてパターン (1)を採用することとした.

（5）堤防背後の最高水位と堤外側の最高水位の関係

一次元津波遡上計算で得た堤防内外の最高水位の関係 は, 各周期について図-11〜 14 のように整理できた. 堤内側と堤外側の最高水位の間には津波の周期毎に関連 性が認められ，津波の周期が長いほど堤外側と堤内側の 水位比が小さくなる.これらの図により，既知である堤 外の最高水位, 津波の周期, 堤防高から堤防内側の最高 水位を算定することとした。

\section{5. 背後地被害の想定}

（1）被害想定の流れ

東南海・南海地震同時発生による高知海岸仁ノ工区の 津波遡上を刘象に，本手法と平面 2 次元津波遡上計算 (加藤ら，2006）の結果を比較し, 本手法の検証を行っ た. 初期潮位は朔望平均満潮位とし, 堤防高（現況 $T$. P.+9.81 m）が地殼変動により $1.98 \mathrm{~m}$, 地震動により $3.44 \mathrm{~m}$ 下がると仮定した. 津波遡上計算では，河川流 量と土砂移動は考慮せず，水門・樋門は全て閉じている と設定した. 本手法では、レベル湛水法で決定された北 側の浸水先端と堤防背後の最高水位を用いて、堤防背後 から南北方向の最高水位を直線補間で決定した後、堤防 端部での南北方向の最高水位分布と東西側の浸水先端を

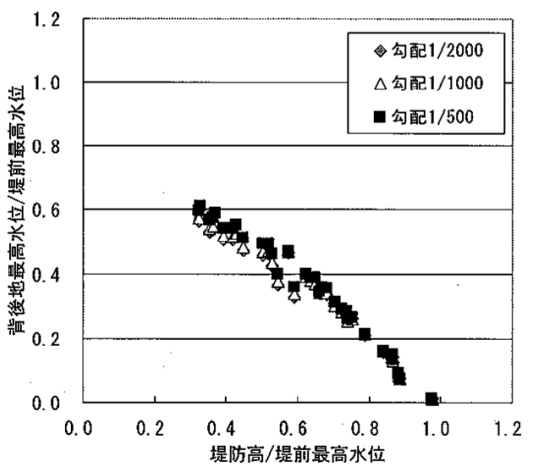

図-11 堤内外の最高水位の関係（周期 5 分）

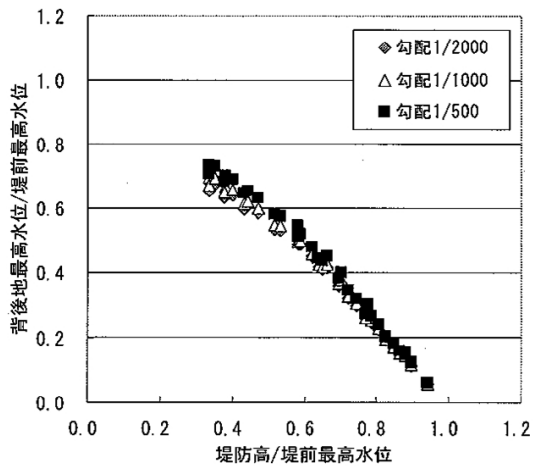

図-12 堤内外の最高水位の関係（周期 10 分）

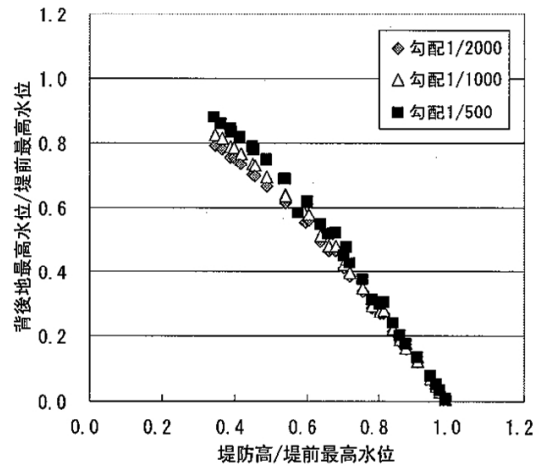

図-13 堤内外の最高水位の関係（周期 20 分）

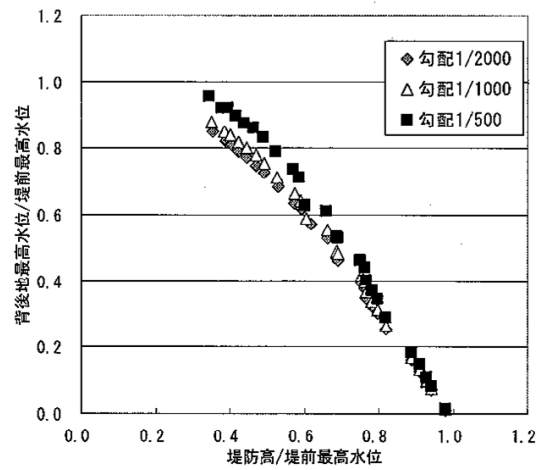

図-14 堤内外の最高水位の関係（周期 30 分） 


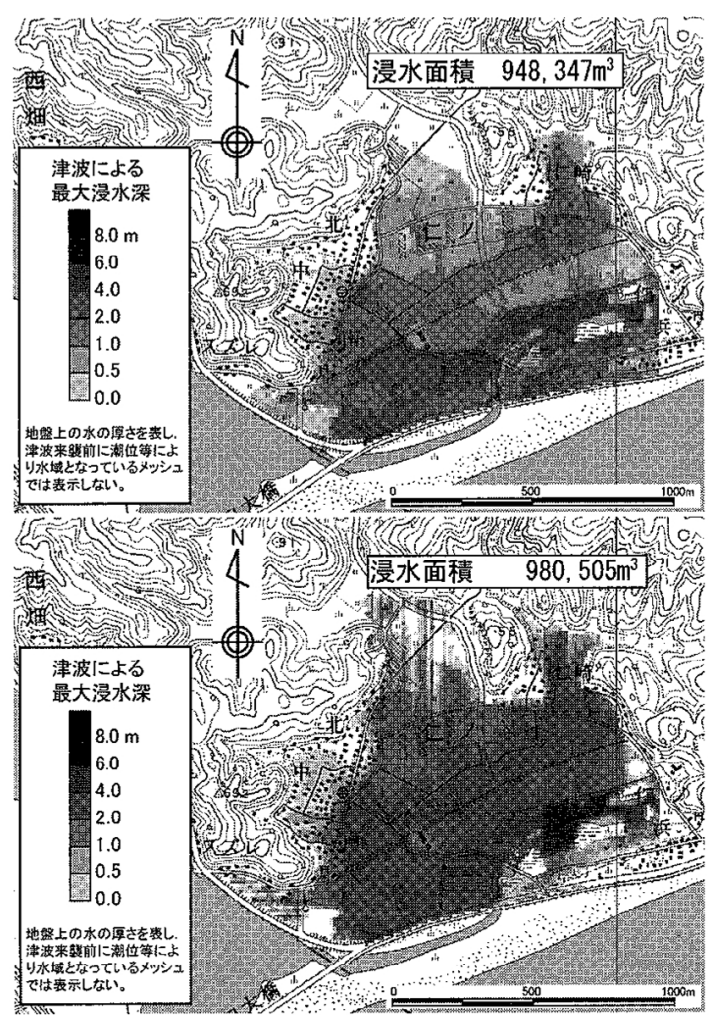

図-15 最大浸水深の分布（上：遡上計算, 下：本手法）

用いて堤防背後以外での東西方向の最高水位分布を直線 補間で決定した。

家屋被害および人的被害の想定には，前述の中央防災 会議の被害関数を用いた。この手法では津波到達時間や 避難意識により死者率が補正されるが，本研究では最悪 のケースを想定して補正を行わなかった.

仁ノ工区の背後地は集落が散在しており，人口・資産 の分布に偏りが見られる．被害想定手法間の差をより正 確に把握するため，津波遡上計算に用いた各格子（11.1 $\mathrm{m}$ 四方）に 1 軒の建物が存在すると仮定し，人的・家 屋被害を推定した。なお， 1 軒当たりの人数は 2.7 人と した.

\section{（2）被害想定手法の検証結果}

中央防災会議の東南海・南海地震同時発生の初期変位 は仁淀川河口に対して図-3のタイプに該当し，仁淀川 河口での津波周期は 13 分と算定された。また，津波遡 上計算により堤防前面海域の最高水位は T.P. $+6.77 \mathrm{~m}$ と推定され，堤防延長を $1,214 \mathrm{~m}$ として式（5）に代入 すると総越流量は 186 万 $\mathrm{m}^{3}$ と計算された。さらに， 図-12 から堤防背後の最高水位は T.P. $+2.77 \mathrm{~m}$ と算出 された。

以上の結果から浸水深分布を想定したところ，図-15

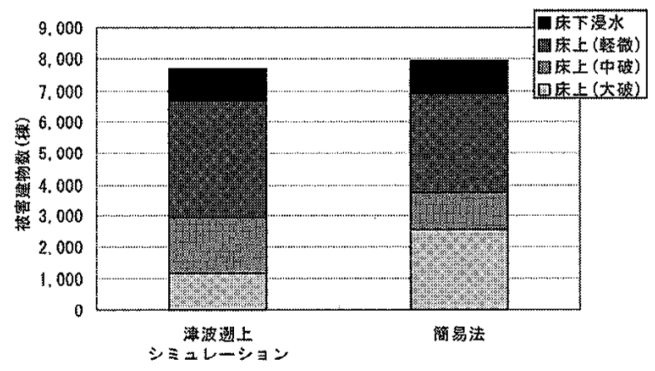

図-16 家屋被害の推定結果

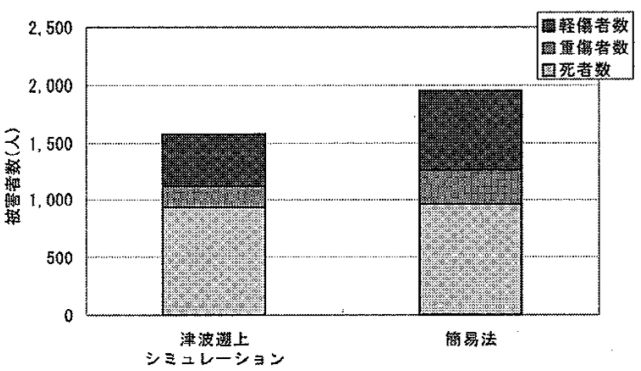

図-17人的被害の推定結果

のように，本手法で得られた最大浸水哚分布は，平面 2 次元津波遡上計算よりやや深めに予測されているものの， 浸水面積の誤差は $3 \%$ \%゙っった。また，図-16および 17 のように，家屋・人的被害についても本手法は被害を大 きく予測しているが，平面 2 次元津波遡上計算と比べて 著しく乘離してはいないので, 本手法により遡上計算と 概坓同じ精度で背後地の被害を想定できると考える。

\section{6. おわりに}

本手法では堤防沈下などを想定した多数のケースにつ いて浸水域抒よび家屋・人的被害が簡易に推定可能であ り，堤防の嵩上げや耐震化などの被害軽減効果を容易に 評価できる。

本研究の実施に際し, 四国地方整備局高知河川国道事 務所から海岸堤防の耐震調查成果を㧍借りした。ここに 記して謝意を表します。

\section{参 考 文 献}

加藤史訓 - 福濱方哉・藤井裕之 - 高木利光 (2006)：地形変化 および海岸堤防の変状を考慮した津波被害想定手法, 海 岸工学論文集, 第 53 巻, pp. 1351-1355.

土木学会原子力土木委員会津波評価部会 $(2002)$ ：原子力発電 所の津波評価技術, p. 2-53.

農林水産省・国土交通省 (2004)：海岸事業の費用便益分析指 針 (改訂版), 103p.

宮城県防災会議地震対策等専門部会 (2004)：宮城県地震被害 想定調查に関する報告書, p. 2-3. 